\title{
Food Numeracy: Definition and Application Across the Australian Secondary School Curriculum
}

\author{
Shirin Shakeri ${ }^{1}$, Karen P McDaid ${ }^{2}$, Judith Fethney ${ }^{3}$ \\ ${ }^{1}$ School of Indigenous Futures, Education \& the Arts, Charles Darwin University, Australia \\ ${ }^{2}$ School of Education, Western Sydney University, Australia \\ ${ }^{3}$ Faculty of Medicine \& Health, University of Sydney, Australia \\ Correspondence: Shirin Shakeri, Charles Darwin University, Australia.
}

Received: May 30, $2021 \quad$ Accepted: June 30, $2021 \quad$ Online Published: July 4, 2021

doi:10.11114/jets.v9i7.5283 URL: https://doi.org/10.11114/jets.v9i7.5283

\begin{abstract}
Introduction: The poor dietary intake among adolescents and the consequential health, economic and environmental concerns associated with poor intakes have been established in the literature. This calls for strengthening of school-based food and nutrition education interventions as recommended in the Australian National Action Plan for the Health of Children and Young People (2020-2030). One researched intervention, by the authors, is the integration of food literacy and food numeracy (FL\&FN) across Australian secondary school curriculum. Aim: Food numeracy is a newly introduced term by the authors; this paper provides its substantiated definition, key elements, and an example pedagogy as an approach for integration and application across the curriculum. Methods: Methodologically, a review of scholarly peer-reviewed and grey litearture, and thematic analysis of all secondary school curriculum documents (years 7-10) have been conducted. Results: Food numeracy is defined as the ability to use mathematical skills effectively to partake of daily requirements and be aware of its value from farm to fork. Additionally, two food numeracy key elements of food production and food consumption with several sub-elements with their corresponding curriculum descriptors have been deduced from the curriculum documents. Finally, practical application and integration of food numeracy across all subjects has been demonstrated using deduced food numeracy and relevant numeracy elements from the Australian curriculum. Conclusion/future implication: It is anticipated that integration of food numeracy across the curriculum can strengthen adolescents' knowledge and skills in both food and nutrition, and numeracy which has a direct correlation with enhanced health status. Introduction and application of food numeracy aligns with contemporary teaching practices which aim to inspire students to use analytical thinking to solve food-related problems and become conscientious global citizens.
\end{abstract}

Keywords: food numeracy, numeracy, secondary schools, curriculum, adolescents

\section{Introduction}

Poor dietary intake among the Australian population [Australian Bureau of Statistics (ABS), 2017] has contributed to health [Australian Institute of Health and Welfare (AIHW), 2020], economic (PricewaterhouseCoopers, Australia, 2015), and environmental concerns (Friel, Barosh, \& Lawrence, 2013). Examples of poor dietary intake among Australian adolescents are provided in the Australian Health Survey: Consumption of Food Groups from the Australian Dietary Guidelines (2011-12) (ABS, 2017) (Tables 1 and 2). Table 1 shows the significant non-compliance with the Australian Dietary Guidelines (National Health and Medical Research Council, 2013) among both genders (aged 12-18), and Table 2 shows significant intake of energy from discretionary food items, added sugars, and saturated and trans fats.

Table 1. Proportion of adolescents meeting daily recommended serves of food groups* by gender and age

\begin{tabular}{l|l|l|l|l}
\hline & \multicolumn{3}{l}{ Proportion of adolescents meeting the recommendations* } \\
\hline \multirow{2}{*}{ Food group* } & Aged 12-13 years & \multicolumn{2}{l}{ Aged 14-18 years } \\
\cline { 2 - 5 } & Girls & Boys & Girls & Boys \\
\hline Fruits & $34.1 \%$ & $33.9 \%$ & $28.2 \%$ & $25.7 \%$ \\
\hline
\end{tabular}




\begin{tabular}{l|l|l|l|l}
\hline Vegetables, legumes/beans & $0.4 \%$ & $0.4 \%$ & $0.7 \%$ & $0.5 \%$ \\
\hline Milk, cheese, yoghurt, and alternatives & $1.8 \%$ & $3.9 \%$ & $0.5 \%$ & $2.5 \%$ \\
\hline Lean meats and alternatives & $0.7 \%$ & $4.2 \%$ & $1.4 \%$ & $14.9 \%$ \\
\hline Grain (cereal) foods & $26.7 \%$ & $34.9 \%$ & $4.6 \%$ & $22.8 \%$ \\
\hline
\end{tabular}

* As recommended by the National Health and Medical Research Council (2013).

Source: Australian Bureau of Statistics (ABS) (2017).

Table 2 . Source of total energy intake by adolescents by age*

\begin{tabular}{l|l|l}
\hline Source of energy & Age 12-13 years & Age 14-18 years \\
\hline Discretionary foods & $40 \%$ & $41 \%$ \\
\hline Added sugars (recommendation $<10 \%^{*}$ ) & $12 \%$ & $13 \%$ \\
\hline Saturated and trans fats (recommendation $\leq 10 \% \%^{* *}$ ) & $14 \%$ & $13 \%$ \\
\hline
\end{tabular}

* World Health Organization (2020)

** National Health and Medical Research Council and New Zealand Ministry of Health (2006)

Source: Australian Institute of Health and Welfare (2018)

\subsection{Diet-related Health Concerns}

Research has shown an association between the lack of compliance with the Australian Dietary Guidelines (ABS, 2017) (Tables 1,2) and rising rates of overweight and obesity among those aged $\geq 5$ between 1995 and 2017-18, as reported by the Australian Institute of Health and Welfare (AIHW, 2019a; AIHW, 2020) (Figure 1).

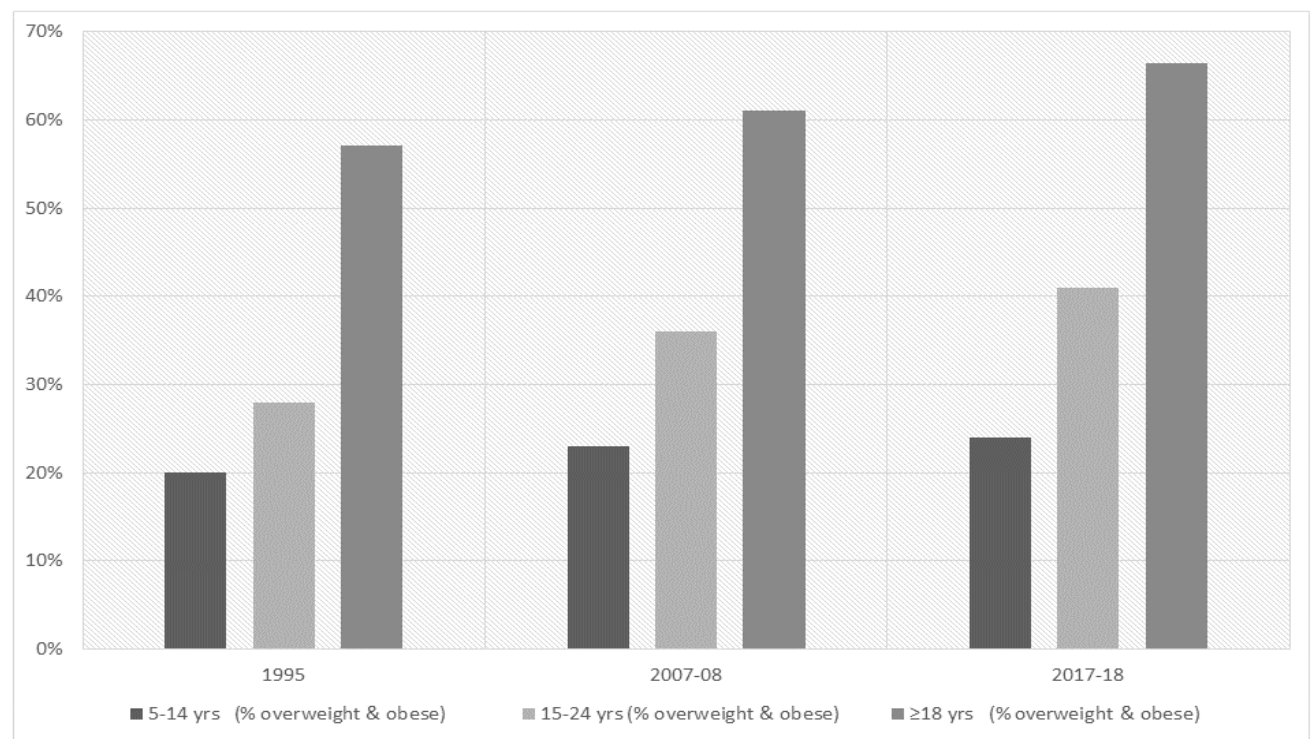

Figure 1. Rising rates of overweight and obesity among those aged $\geq 5$ from 1995 to 2017-18

Based on the Australian Burden of Disease Study 2015, this rise has been linked to asthma from age $\geq 5$ years and to 14 types of cancer from age $\geq 15$ years (AIHW, 2019b). Research has also established a potential correlation between poor dietary intakes and the increasing rate of mental-health concerns among adolescents. For instance, Kulkarni, Swinburn, \& Utter (2015) showed an association between quality of diets and mental health among socially disadvantaged New Zealand adolescents (mental-health score was lower by five points in adolescents consuming nutrient poor diets).

\subsection{Diet-related Economic Concerns}

In 2011-2012, the financial cost of overweight and obesity to the Australian economy was $\$ 8.6$ billion (AIHW, 2019c). If no further action is taken to slow the rise in obesity, the projected cost is estimated to increase to $\$ 87.7$ billion from 2015-16 to 2024-25 (AIHW, 2020; PricewaterhouseCoopers Australia, 2015). However, Black, Kung, \& Peeters (2018) argue that long-term economic impacts such as the link found between obesity at age 16 and lower household income in adulthood in males may not be considered in economic projections cited above. 


\subsection{Diet-related Environmental Concerns}

According to the Food and Agriculture Organization of the United Nations (FAO) (2012), sustainable diets should be protective of biodiversity and ecosystems, economically affordable, and nutritionally adequate. Production and consumption of energy dense, nutrient poor, ultra-processed discretionary foods, as indicated in Table 2, have resulted in higher emission of greenhouse gases, water usage, and loss of biodiversity (Friel et al., 2013).

\subsection{Addressing Diet-related Concerns}

The Australian National Action Plan for the Health of Children and Young People (2020-2030) provides recommendations to address diet-related health concerns (Department of Health, 2019). One of these recommendations is supporting school-based interventions that enhance the nutrition and physical activity status of students (AIHW, 2020). An example of an intervention that potentially aligns with the above recommendation is the integration of FL\&FN across the Australian secondary school curriculum, as researched by the authors (Shakeri, Bucher, Eather, \& Riley, 2020; Shakeri, Fethney, Rolls, Papatraianou, \& Myers, 2021). As stated, integration of FL\&FN across all subjects can facilitate greater opportunities to enhance adolescents' food and nutrition knowledge and skills. This integrative approach can enable students to learn, experiment and develop healthy eating behaviours that enhance their health and their contribution at economic, and environmental levels. However, integrative pedagogies are complex and require in-depth investigations (Shakeri et al., 2020).

A definition of food literacy (Vidgen \& Gallegos, 2014), and its application in Australian secondary schools (Fordyce-Voorham, 2017; Ronto, 2017) has been provided in the literature. Food numeracy was introduced by Shakeri et al. to complement the term food literacy with the consideration that in the Australian curriculum, literacy and numeracy are two complementary but distinct General Capabilities which are familiar to teachers and are integrated and strengthened across all subjects [Australian Curriculum Assessment and Reporting Authority (ACARA), 2017]. Additionally, research has shown a positive correlation between enhanced numeracy skills and health status [Organisation for Economic Co-operation and Development (OECD), 2018]. It is anticipated that the integration of food numeracy across all subjects can enhance both numeracy and food and nutrition knowledge and skills that correlate with higher health status. It can also facilitate further integration of mathematical concepts of food and nutrition across subjects with mathematical contents (Shakeri et al., 2020). Hence, the aim of this article is to provide the outcome of further research undertaken to provide a substantiated definition, key elements, and application of this newly introduced term across the Australian secondary school curriculum.

\section{Method}

\subsection{Introduction of food Numeracy}

This first stage was achieved by a search of relevant scholarly peer-reviewed articles to explore the importance of numeracy in relation to health. This provided justification for the introduction of this new term.

\subsection{Developing a Definition for Food Numeracy}

This second stage was achieved by further search of relevant scholarly peer-reviewed and grey literature with one keyword, 'numeracy'. The aim of this search was to ascertain the history of the introduction of numeracy, its established definition in the literature, its characteristics and elements, and its current application in the Australian curriculum. A detailed review of these retrieved articles provided a scaffold for the definition of food numeracy, which is aligned with the characteristics of numeracy in essential skills (Table 3) (Neil, 2001), and established elements of numeracy (Table 4) (ACARA, 2017).

\subsection{Developing Key Elements for Food Numeracy}

This third stage is linked with the study conducted in 2020 by Shakeri et al., which involved an analysis of New South Wales curriculum documents (Years 7-10). The outcome of their analysis was tabulation of the frequency of appearance of two key words 'food' and 'nutrition' in all curriculum descriptors within the curriculum documents (Table 5).

In 2021, the authors of this paper conducted a subsequent analysis of the curriculum documents i.e., they extracted all curriculum descriptors containing 'food' and 'nutrition' terms and distilled the descriptors which refer to both food/nutrition and elements of numeracy skills. These descriptors were then uploaded and further analysed using Nvivo software (Version 12, 2018) using a deductive approach (Braun, \& Clarke, 2014) to derive key elements and sub-elements for food numeracy (Table 6).

\subsection{Developing A Pedagogical Example for Application and Integration of Food Numeracy Across Curriculum}

This final stage involved further search of relevant scholarly and grey literature to explore the application and integration of numeracy across the curriculum. Based on this comparison, one pedagogy example was designed to demonstrate the application and integration of food numeracy in one or more secondary school subjects as a practical 
guide for teachers (section 3.4.2 and Figure 2). This was performed by the authors who have training in both food and nutrition and mathematics education with reference to the deduced food numeracy element and relevant numeracy element in the Australian curriculum (ACARA, 2017).

\section{Results}

\subsection{Introduction of Food Numeracy}

The term 'food numeracy' has been introduced based on two considerations, as examined in sections 3.1.1 and 3.2.1.

\subsubsection{Association Between Numeracy Skills and Health}

An association between enhanced levels of numeracy skills and health was signified in an early study of weight-loss programs which showed that their mechanism is based on quantification of food i.e., controlling food portion sizes (Lave, 1988). These programs required consumers to incorporate numeracy skills into their everyday food practices to enhance their health outcome.

Several other studies have examined the beneficial role of numeracy skills on health. For instance, in 2008, Huizinga, Beech, Cavanaugh, Elasy \& Rothman, conducted a study with 160 participants. They found that individuals with a mean Body Mass Index (BMI) $\geq 30$ were significantly more likely to have low numeracy ( $<9$ th-grade level), than those with a BMI $<30(P=.033)$. Conversely, when numeracy level was categorised as a variable, participants with low numeracy ( $<9$ th-grade level) had a higher mean BMI of 31.8 compared to those with a higher numeracy level ( $>9$ th-grade), who had mean BMI of 27.9 ( $\mathrm{P}=0.008)$. One limitation of this study was that the numeracy skills related to behaviours such as reading nutrition labels and estimating portion sizes were not tested to gain a complete understanding of the impact of numeracy skills on BMI. Therefore, in their 2009 study, Huizinga et al., examined the correlation between numeracy skills and portion size estimation. In this study, participants $(n=164)$ were administered the Wide Range Achievement Test- $3^{\text {rd }}$ Edition (Snelbaker, Wilkinson, Robertson, \& Glutting, 2001). Findings from this study indicated that $95 \%$ of participants with lower numeracy skills overestimated portion sizes.

In another 2009 study, Carpentieri, Lister, \& Frumkin, reported that "initial studies have shown that adults with poor numeracy are 2.5 times more likely to report having a long-standing illness or disability" (p.11).

In 2018, a report released by the OECD, on 'Numeracy practices and numeracy skills among adults' stated that the probability of reporting good to excellent health is on average $22 \%$ higher for adults at level 4 or 5 numeracy than for adults at level $\leq 1$. The actual probability percentage was $27.5 \%$ higher among individuals aged $16-25$, and $32 \%$ higher among aged 55-65.

Finally, a pilot study conducted by Follong, Prieto-Rodriguez, Miller, Collins, \& Bucher (2020) found that a potential integration of food portion size education within Australian primary school Mathematics curriculum Units and Measurement can have benefits for both nutritious eating and improved numeracy skills.

These studies are significant as research has shown a significant rise in median portion sizes of some discretionary foods from 1995 to 2011-12 (e.g., pizza and cake displaying increases of 66\% in portion sizes), promoting overeating, and increased daily energy intake (+570 kJ to $+950 \mathrm{~kJ}$ ) (AIHW, 2020; Zheng, Rangan, Meertens, \& Wu, 2017). Hence, there is a valid justification for introducing food numeracy which aims to enhance numeracy skills related to food and nutrition skills.

\subsection{Defining Food Numeracy}

3.2.1 Familiarity of Teachers With the Definition, Characteristics, Elements, and Application of Numeracy

This familiarity was an additional justification for the introduction of food numeracy and provided a framework for the definition and application of food numeracy.

\subsubsection{Definition of Numeracy}

In 1997, the Australian Association of Mathematics Teachers (AAMT) Policy on Numeracy defined numeracy as the ability "to use mathematics effectively to meet the general demands of life at home, in paid work, and for participation in community and civic life" (Department of Employment, Education, Training and Youth, 1997, p. 2). This policy elucidates factors, such as declining rates of mathematical skills and disassociation of mathematical knowledge from real life practices, as reasons for introducing and teaching numeracy skills across all subjects. Introduction and integration of numeracy across all subjects and as a General Capability in the Australian Curriculum was welcomed by this Association as it signified the central role of mathematics in everyday life and, ultimately, in Australia's future economic and social prosperity (AAMT, 1997). It is anticipated that introduction and integration of food numeracy across the curriculum is a further proclamation of the significant role of both numeracy and food and nutrition 
knowledge and skills and may address the declining rates of adequate knowledge and skills in food and nutrition in adolescents (Shakeri et al., 2020).

\subsubsection{Characteristics of Numeracy}

In 2001, Neil, developed 'Characteristics of Numeracy in Essential Skills' based on the New Zealand Curriculum Framework (Table 3), and elucidated that "at school numeracy should be developed and exhibited across all seven essential learning areas. Out of school, numeracy should be exhibited in a range of situations that most students experience in everyday life" (p.9).

Table 3. Characteristics of Numeracy in Essential skills (Neil 2001)*

\begin{tabular}{l}
\hline Characteristics of numeracy (examples \& competencies for numeracy skills) ${ }^{*}$ \\
\hline Common, real-life situation \\
e.g., measuring, and mixing quantities, or shopping \\
\hline Cross-curricula contexts used \\
e.g., drawn from Science, Technology, Social Studies, English, Art, and Health \\
\hline Competencies of a global nature are exhibited. \\
e.g., choosing to use mathematics to - \\
Interpret, critically evaluate, and communicate statements of a mathematical nature
\end{tabular}

*Source: Neil, 2001: The essentials of numeracy

\subsubsection{Elements of Numeracy}

In the Australian curriculum, the key elements for numeracy are organised into interrelated elements and associated sub-elements in the 'Numeracy Learning Continuum' (Table 4) (ACARA, 2017).

Table 4. Some elements \& sub-elements of numeracy in the 'Numeracy Learning Continuum' in the Australian Curriculum (2017)*

\begin{tabular}{l|l}
\hline Elements & Sub-elements \\
\hline Number sense and algebra & Operating with decimals and percentages \\
& Comparing units (ratios, rates, and proportions) \\
& Interpreting fractions \\
Measurements and geometry & Understanding units of measurement \\
Statistics and probability & Interpreting and representing data \\
\hline
\end{tabular}

*Source: Australian Curriculum, Assessment and Reporting Authority (ACARA), 2017.

\subsubsection{Definition of Food Numeracy}

The definition of food numeracy, devised by Shakeri et al., is based on the characteristics of numeracy in essential skills (Table 3) (Neil, 2001) and elements of numeracy-Learning Continuum in the Australian curriculum (Table 4) (ACARA, 2017). As defined by the authors "food numeracy involves application of numbers, patterns, statistics, graphics, and measurement to critically evaluate, interpret, and communicate mathematical information related to a diversity of food practices. In simple words, to be food numerate is to use applied mathematical knowledge and skills (numeracy skills) effectively to partake of daily food requirements and be fully conscious of its value from farm to fork."

\subsection{Key Elements for Food Numeracy}

Table 5 shows the outcome of the initial analysis of all NSW curriculum documents (Years 7-10) with reference to the appearance of two key words, 'food' and 'nutrition'. As shown, English and Arts have the lowest integration; subjects such as Science and Health and Physical Education have moderate integration of food and nutrition; and Technologies has the highest content of food and nutrition concepts (Shakeri et al., 2020). 
Table 5. Frequency of the appearance of the terms, 'food' and 'nutrition' in each learning area*

\begin{tabular}{lll}
\hline Learning Areas & Frequency of 'food' & Frequency of 'nutrition' \\
\hline English & 0 & 0 \\
Mathematics & 3 & 1 \\
Science & 31 & 1 \\
Technologies & 841 & 81 \\
Humanities and Social Sciences & 7 & 0 \\
Health and Physical Education & 71 & 56 \\
The Arts & 0 & 0 \\
\hline
\end{tabular}

*Source: NSW curriculum documents (NESA, 2020) (ACARA, 2020); Shakeri et al., 2020.

Table 6 shows the outcome of the subsequent analysis of the curriculum documents by the authors as described in section 2.3. Two key elements of food production and food consumption with their relevant sub-elements and corresponding curriculum descriptors have been deduced.

The aim is to provide teachers with existing curriculum descriptors that can be used across all subjects regardless of presence or absence of food and nutrition content in their related curriculum document. Hence, no new concepts are introduced in an already overcrowded curriculum.

Table 6. Food numeracy key elements, sub-elements, and corresponding curriculum descriptors

\begin{tabular}{|c|c|c|c|}
\hline \multicolumn{4}{|c|}{ Food numeracy Key elements } \\
\hline Food production & & Food consumption & \\
\hline Sub-elements & Curriculum descriptors & Sub-elements & Curriculum descriptors \\
\hline $\begin{array}{l}\text { Food imports and } \\
\text { exports }\end{array}$ & $\begin{array}{l}\text { Investigate the importance of food } \\
\text { and fibre production to Australia's } \\
\text { food security and economy } \\
\text { including Asia's imports \& exports }\end{array}$ & Food choices & $\begin{array}{l}\text { Evaluate the influence of nutritional } \\
\text { value, value for money and } \\
\text { sustainability on personal food } \\
\text { choices and behaviours, e.g., } \\
\text { home-cooked vs. takeaway meals }\end{array}$ \\
\hline Food marketing & $\begin{array}{l}\text { Evaluate the profitability of an } \\
\text { agricultural plant enterprise }\end{array}$ & $\begin{array}{l}\text { Food consumption } \\
\text { inequality }\end{array}$ & $\begin{array}{l}\text { Interpret data displays representing } \\
\text { two or more dependent numerical } \\
\text { variables against time, e.g., compare } \\
\text { the daily food intake of different } \\
\text { countries over time }\end{array}$ \\
\hline Food security & $\begin{array}{l}\text { Identify necessities for living } \\
\text { independently, e.g., cost of food }\end{array}$ & $\begin{array}{l}\text { Healthy food } \\
\text { consumption }\end{array}$ & $\begin{array}{l}\text { Analyse a variety of food labels to } \\
\text { help make informed and healthy } \\
\text { choices when purchasing food for } \\
\text { children }\end{array}$ \\
\hline $\begin{array}{l}\text { Nutrition } \\
\text { information panel } \\
\text { for food production }\end{array}$ & $\begin{array}{l}\text { Recognise and interpret data related } \\
\text { to food production, e.g., nutritional } \\
\text { information panels }\end{array}$ & $\begin{array}{l}\text { Nutritional needs } \\
\text { of groups }\end{array}$ & $\begin{array}{l}\text { Investigate Recommended Dietary } \\
\text { Intake (RDI) for various life stages, } \\
\text { design and prepare meals to meet } \\
\text { specific groups }\end{array}$ \\
\hline $\begin{array}{l}\text { Plant } \\
\text { production }\end{array}$ & $\begin{array}{l}\text { Acquire and interpret data, e.g., } \\
\text { local environmental and/or physical } \\
\text { conditions (rainfall, temperature, or } \\
\text { nutrition information panels, e.g., } \\
\text { saturated fat) }\end{array}$ & $\begin{array}{l}\text { Patterns in food } \\
\text { consumption }\end{array}$ & $\begin{array}{l}\text { Communicate an understanding of } \\
\text { trends, patterns, and relationships in } \\
\text { data to a specified audience, e.g., } \\
\text { explore food-consumption patterns in } \\
\text { Australia and its impact on nutrient } \\
\text { intake and health }\end{array}$ \\
\hline School garden & $\begin{array}{l}\text { Manage and monitor crops to } \\
\text { raise/grow products on the school } \\
\text { farm, e.g., grow a crop from seed to } \\
\text { harvest }\end{array}$ & $\begin{array}{l}\text { Recipe } \\
\text { modification } \\
\text { catering }\end{array}$ & $\begin{array}{l}\text { Explore menu-planning } \\
\text { considerations, e.g., cost, converting } \\
\text { measurement, applying ratios and } \\
\text { rates, impact on environment. }\end{array}$ \\
\hline $\begin{array}{l}\text { Sustainable } \\
\text { production }\end{array}$ & $\begin{array}{l}\text { Analyse a variety of data displays } \\
\text { used in the print or digital media } \\
\text { and in other school subject areas, } \\
\text { e.g., data displays showing } \\
\text { sustainable food production }\end{array}$ & $\begin{array}{l}\text { Recipe } \\
\text { modification for } \\
\text { food security }\end{array}$ & $\begin{array}{l}\text { Design, plan and prepare safe and } \\
\text { nutritious food items appropriate to } \\
\text { specific situations, e.g., rural } \\
\text { communities, low-socioeconomic } \\
\text { groups }\end{array}$ \\
\hline
\end{tabular}




\subsection{A Pedagogical Example for Application and Integration of Food Numeracy Across the Curriculum}

\subsubsection{Application and Integration of Numeracy Across the Curriculum}

Since 1997, application and integration of numeracy skills across all subjects has been facilitated through provision of teacher training and teaching resources by the Departments of Education in each state and territory in Australia (ACARA, 2017), as well as various interventions conducted by tertiary institutions. For instance, in 2019, Forgasz \& Hall, studied the impact of a compulsory pedagogy unit that integrated numeracy across all learning areas on student teachers. This unit, called 'Numeracy for Learners and Teachers', was introduced in 2015 to the Master of Teaching at Monash University in Victoria (Australia). They found that students' confidence to incorporate numeracy into their teaching across the curriculum improved after studying the unit.

It is anticipated that application and integration of food numeracy across the curriculum can be facilitated through similar teacher training interventions. To this end, the lead author is conducting an additional study to investigate the benefit of professional learning development workshops on food numeracy with the student teachers of all secondary disciplines at a tertiary institution. The aim is to evaluate the benefit of these workshops on the student teacher's knowledge and skills in food numeracy and their ability to integrate food numeracy into their specialised secondary subjects.

The potential application of food numeracy across the secondary school curriculum can be described with the aid of the following example, as designed by the authors. In practice, teachers can be given similar research studies which refer to one of the food numeracy key-elements/sub-elements. Teachers can decide to teach the research study employing any suitable elements of numeracy from the curriculum.

\subsubsection{A Pedagogical Example}

\subsection{Research Study}

In 2013, Friel et al., developed the concept of Healthy and Sustainable food baskets (low environmental impact food items) which contribute to food and nutrition security and to healthy life for present and future generations. These food items are considered protective of biodiversity and ecosystems, economically fair, and nutritionally adequate (FAO, 2012). The authors calculated and tabulated the value of a typical food basket versus a Healthy and Sustainable food basket. They calculated two variables i.e., water usage and $\mathrm{CO}_{2}$ emission for categorisation of each item.

\subsection{Food Numeracy Element}

This research is relevant to the first key-element of food numeracy, food production (sub-element: sustainable food production and the corresponding curriculum descriptor - Table 6), which can be studied and analysed in several subjects such as Mathematics.

\subsection{Pedagogy Solution}

Teachers can interpret and represent the data from the table devised by Friel et al., (2013) in a healthy and sustainable food pyramid (Figure 2) using a suitable numeracy element (Table 4) (e.g., element: statistics and probability; sub-element: interpreting and representing data). This can generate classroom discussions about what each section and order of the food pyramid represents and can be the basis for generating a healthy food-based investigation, integrated across multiple subjects. 


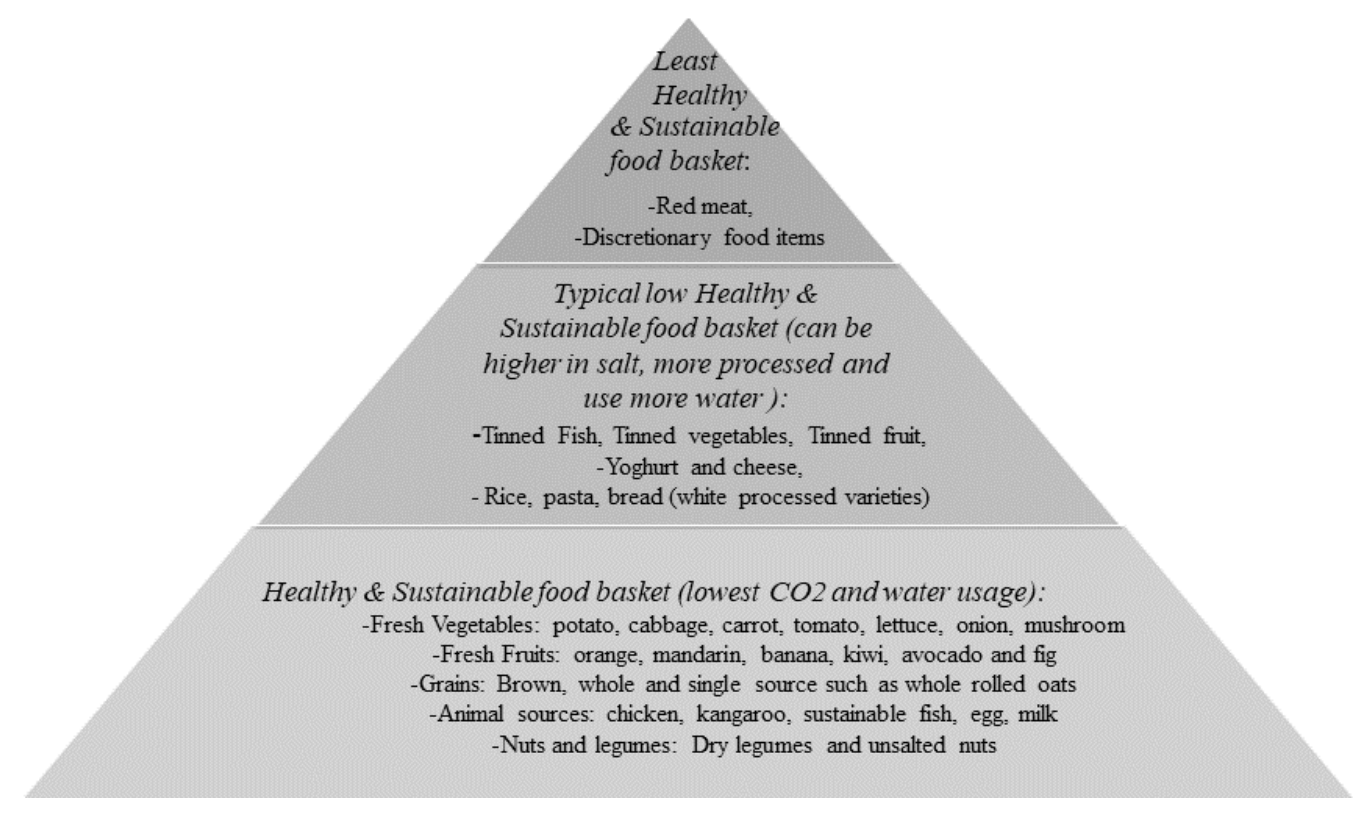

Figure 2. Healthy and Sustainable food basket pyramid (Shakeri et al., 2021)

\section{Discussion}

This paper has outlined justifications for the introduction and application of food numeracy across the curriculum which may address some of the health, economic, and environmental concerns related to poor dietary intake. Firstly, research has shown a significant correlation between higher numeracy skills and diet-related health status. Secondly, teachers' familiarity with numeracy application and integration across the curriculum can be employed as a vehicle to concurrently integrate food numeracy across the curriculum. This can potentially enhance both numeracy and food and nutrition knowledge and skills across all subjects.

The devised definition for food numeracy aligns with the characteristics and elements of numeracy within the context of Australian secondary schools' curriculum. Similarly, the key-elements are deduced from the Australian secondary school curriculum and provide a general framework for secondary teachers to integrate food numeracy into their own lessons.

Integration of food numeracy across the curriculum may be impacted by factors such as lack of research-based teaching resources and teacher training. Hence, the lead author will be undertaking future studies into the development of digital teaching resources for food numeracy which can present a model to engage non-specialist teachers to teach subjects with both mathematical and food and nutrition content in a way that is engaging, and educational. Teacher professional development provides a justification for the lead author to undertake a pilot case study with student teachers of all disciplines at a tertiary institution to evaluate the benefit of teacher professional development on their knowledge and skills of food numeracy and capacity to integrate it into their own chosen subject. It is envisaged that including a unit on food numeracy education in all teaching qualifications and teacher education programs may address this barriers and benefit students and teachers as they learn to apply food numeracy for healthier, more economical, and sustainable food practices.

\section{Conclusion/Implications for Future}

It is anticipated that food numeracy can enable students to recognise and comprehend the important role of mathematics in solving everyday food-related problems such as comprehending nutrition information panel on foods and food budgetting. Food numerate students can also become empowered to interpret and evaluate mathematical data and communicate mathematical reasoning in real world situations dealing with global concerns, such as food insecurity and food systems' unsustainability. Enhancing adolescents' food numeracy skills can mutually strengthen their numeracy skills while alerting them to the cost of their poor dietary intake on health, economy, and environment. For instance, climate change is a rising concern among adolescents and learning food numeracy concepts, such as costs of unsustainable farming practices, can act as conduits for adolescents to channel their concerns into appropriate action by changing to more plant-based diets. Hence, it is envisaged that integration of food numeracy concepts will create classroom discussions which are research-based and proactively focus on the broader impact of individual dietary behaviours on health, economy, and environment. 


\section{Strengths/Limitations}

This study employed a comparative method to devise the definition and application of food numeracy in comparison with the definition, characteristics, elements, and application of numeracy in the Australian secondary school curriculum. It also employed an analytical method to deduce key-elements and sub-elements for food numeracy from within the curriculum. These methods have been conducted by the authors who have extensive knowledge and skills in research, food and nutrition, mathematics, and secondary teaching. Additional plans to conduct a pilot case study on application and integration of food numeracy with student teachers at a tertiary institution will provide further evaluations of this current study. However, future studies are required to further evaluate the impact of food numeracy teaching resources and teacher professional development on teachers and students.

\section{References}

Australian Bureau of Statistics. (2017). Australian Health Survey: Consumption of Food Groups from the Australian Dietary Guidelines, 2011-12 [Cat. no. 4364.0.55.012].

https://www.abs.gov.au/AUSSTATS/abs@.nsf/Lookup/4364.0.55.012Main+Features100032011-12?OpenDocume nt

Australian Curriculum Assessment and Reporting Authority. (2017). Numeracy. https://www.australiancurriculum.edu.au/f-10-curriculum/general-capabilities/numeracy/

Australian Curriculum Assessment and Reporting Authority. Curriculum documents. Retrieved 2020, March 25, from https://www.acara.edu.au/curriculum/foundation-year-10/cross-curriculum-priorities

Australian Institute of Health and Welfare (2019c). Health expenditure Australia 2017-18. Health and welfare expenditure series no.65. Cat. no. HWE 77. Canberra: AIHW.

Australian Institute of Health and Welfare. (2018). Nutrition across the life stages [Cat. no. PHE 227]. https://www.aihw.gov.au/getmedia/fc5ad42e08f5-4f9a-9ca4-723cacaa510d/aihw-phe-227.pdf.aspx?inline=true

Australian Institute of Health and Welfare. (2019a). Overweight and obesity: an interactive insight. https://www.aihw.gov.au/reports/overweight-obesity/overweight-and-obesity-an-interactive-insight/contents/whatis-overweight-and-obesity

Australian Institute of Health and Welfare. (2019b). Australian Burden of Disease Study: impact and causes of illness and death in Australia 2015. Cat. no. BOD 22. Canberra: AIHW.

Australian Institute of Health and Welfare. (2020). Overweight and obesity among Australian children and adolescents. Cat. no. PHE 274. Canberra: AIHW.

Black, N., Kung, C. S. J., \& Peeters, A. (2018). For richer, for poorer: the relationship between adolescent obesity and future household economic prosperity. Preventive Medicine, 111, 142-150. https://doi.org/10.1016/j.ypmed.2018.02.034

Braun, V., \& Clarke, V. (2014). "What can thematic analysis offer health and wellbeing researchers?". International Journal of Qualitative Studies in Health Well-being, 9(1), 26152. https://doi.org/10.3402/qhw.v9.26152

Carpentieri, J. D., Litster, J., \& \& Frumkin, L. (2009). Adult numeracy: A review of research. https://www.natio nalnu merac y.org.uk/sites /defau lt/files /carpe ntier i_-et_al_2009_bbc_adult numeracy_a_revie w_of_resea rch.pdf

Department of Employment, Education, Training and Youth Affairs. (1997, May 20-21). Numeracy= everyone's business. Report of the numeracy education strategy development conference. Published by the Australian Association of Mathematics Teachers Inc.

Department of Health. (2019). National Action Plan for the Health of Children and Young People 2020-2030. Canberra (AUST): Australian Government. Retrieved 2021, January 25, from https://www1.health.gov.au/internet/main/publishing.nsf/Content/child-and-youth-action-plan

Follong, B., Prieto-Rodriguez, E., Miller, A., Collins, C., \& Bucher, T. (2020). An exploratory survey on teaching practices integrating nutrition and mathematics in Australian primary schools. International Journal of Research in Education and Science, 6(1), 14-33. https://doi.org/10.46328/ijres.v6i1.566

Food and Agriculture Organization of the United Nations. (2012). Sustainable Diets and Biodiversity. Directions and Solutions for Policy, Research and Action. Rome: FAO.

Fordyce-Voorham, S. P. A. (2017). An evaluation tool for measuring food skills acquisition. British Food Journal, 119(5), 1028-1044. https://doi.org/10.1108/BFJ-07-2016-0312 
Forgasz, H. J., \& Hall, J. (2019). Learning about numeracy: the impact of a compulsory unit on pre-service teachers' understandings and beliefs. Australian Journal of Teacher Education, 44(2). https://doi.org/10.14221/ajte.2018v44n2.2

Friel, S., Barosh, L. J., \& Lawrence, M. (2013). Towards healthy and sustainable food consumption: an Australian case study. Journal of Public Health Nutrition, 17(5), 1156-1166. https://doi.org/10.1017/S1368980013001523

Huizinga, M. M, Beech, B.M., Cavanaugh K. L., Elasy T. A., \& Rothman R. L. (2008). Low numeracy skills are associated with higher BMI. Obesity (Silver Spring), 16(8), 1966-1968. https://doi.org/10.1038/oby.2008.294

Huizinga, M. M., Carlisle, A. J., Cavanaugh, K. L., Davis, D. L., Gregory, R. P., Schlundt, D. G., \& Rothman, R. L. (2009). Literacy, numeracy, and portion-size estimation skills. American Journal of Preventive Medicine, 36(4), 324-328. https://doi.org/10.1016/j.amepre.2008.11.012

Kulkarni, A. A., Swinburn, B. A., \& Utter, J. (2015). Associations between diet quality and mental health in socially disadvantaged New Zealand adolescents. European Journal of Clinical Nutrition, 69(1), 79-83. https://doi.org/10.1038/ejen.2014.130

Lave, J. (1988). Cognition in practice: Mind, mathematics, and culture in everyday life. Cambridge: Cambridge University Press. https://doi.org/10.1017/CBO9780511609268

National Health and Medical Research Council \& New Zealand Ministry of Health. (2006). Nutrient Reference Values for Australia and New Zealand- Executive summary [V. 1.2, updated September 2017]. National Health and Medical Research

Council. https://www.nhmrc.gov.au/sites/default/files/images/Nutrient-reference-aus-nz-executive-summary.pdf

National Health and Medical Research Council. (2013). Australian Dietary Guidelines. https://www.health.gov.au/sites/default/files/australian-dietaryguidelines.pdf

Neill WA. The essentials of numeracy. In: New Zealand Association of Researchers in Education Conference. Christchurch; January 2001. Accessed December 12, 2020, available from, https://www.researchgate.net/publication/250752991_The_Essentials_of_Numeracy/link/546e42d80cf2b5fc17607 213/download

NSW Education Standards Authority (NESA). NSW Syllabus for the Australian Curriculum. Food Technology Years 7-10 Syllabus. Accessed December 15, 2020. https://educationstandards.nsw.edu.au/wps/portal/nesa/k-10/learning-areas/

Nvivo qualitative data analysis software. (2018). QSR International Pty Ltd. Version 12.

Organisation for Economic Co-operation and Development. (2018). Numeracy practices and numeracy skills among adults. Paris: OECD Education Working Papers Series.

PricewaterhouseCoopers (PwC) Australia. (2015). Weighing the cost of obesity: a case for action. Australia: PwC Australia.

Ronto, R. (2017). Examining the role of food literacy in shaping adolescents' dietary behaviours [Doctoral thesis, Griffith University]. https://doi. org/10.25904/1912/2736

Shakeri, S., Bucher, T., Eather, N., \& Riley, N. (2020). Integrating food literacy and food numeracy across Australian secondary school curriculum. Journal of the Home Economics Institute of Australia, 26(1), 25-34.

Shakeri, S., Fethney J., Rolls, N., Papatraianou, L., \& Myers, J. (2021). Integrating food literacy and food numeracy across Australian secondary school curriculum; teachers' opinion in a mixed method study. Journal of Education and Training Studies, 9(4), 49-61. https://doi.org/10.11114/jets.v9i4.5218

Snelbaker A. J., Wilkinson G. S., Robertson G. J., \& Glutting J. J. (2001). Wide Range Achievement Test 3 (wrat3). In: Dorfman W.I., Hersen M. (eds) Understanding Psychological Assessment. Perspectives on Individual Differences. Springer, Boston, MA. https://doi.org/10.1007/978-1-4615-1185-4_13

Vidgen, H. A. (2014). Food literacy: What is it and does it influence what we eat? [Unpublished doctoral thesis]. School of Exercise and Nutrition Sciences, Faculty of Health, Queensland University of Technology. https://eprints.qut.edu.au/66720/1/Helen_Vidgen_Thesis.pdf

World Health Organization. (2020). Reducing free sugars intake in children and adults. https://www.who.int/elena/titles/guidance_summaries/sugars_intake/en/ 
Zheng, M., Rangan, A., Meertens, B., \& Wu, J. (2017). Changes in typical portion sizes of commonly consumed discretionary foods among Australian adults from 1995 to 2011-2012. Nutrients, 9(6), E577. https://doi.org/10.3390/nu9060577

\section{Copyrights}

Copyright for this article is retained by the author(s), with first publication rights granted to the journal.

This is an open-access article distributed under the terms and conditions of the Creative Commons Attribution license which permits unrestricted use, distribution, and reproduction in any medium, provided the original work is properly cited. 